\begin{tabular}{|c|l|}
\hline Title & $\begin{array}{l}\text { Human resource development programs for knowledge transfer and creation : the case of the Toyota Technical } \\
\text { Development Corporation }\end{array}$ \\
\hline Author(s) & Matsuo, Makoto \\
\hline Citation & $\begin{array}{l}\text { Journal of Knowledge Management, 19(6), 1186-1203 } \\
\text { https://loi.org/10.1108/JKM-03-2015-0108 }\end{array}$ \\
\hline Issue Date & 2015 \\
\hline Doc URL & http://hdl.handle.net/2115/60858 \\
\hline Type & article (author version) \\
\hline File Information & Self-archiving (JKM, 2015).pdf \\
\hline
\end{tabular}

Instructions for use 
Journal of Knowledge Management, Vol.19, No.6, 2015, pp. 1186-1203

\title{
Human resource development programs for knowledge transfer and creation: the case of the Toyota Technical Development Corporation
}

\author{
Makoto Matsuo \\ Hokkaido University
}

\begin{abstract}
Purpose - The purpose of this study was to examine how human resource development (HRD) programs promote the linkage between knowledge transfer and knowledge creation in engineering departments.

Design/methodology/approach - This study adopted a case study approach to the Toyota Technical Development Corporation (TTDC), an affiliated company of Toyota Motor Corporation. Data were collected from interviews with managers of the TTDC as well as its internal documents.

Findings - Three major findings can be extracted from the paper. First, The TTDC effectively links knowledge transfer to knowledge creation so that new knowledge on vehicle development is created by transferred competencies. Second, the TTDC promotes the transfer of explicit and tacit knowledge by complementarily combining off-the-job and on-the-job training (OJT). Third, HRD programs are developed and operated in communities of practice.
\end{abstract}

Research limitations/implications - The practices described in this paper are limited to two departments of the TTDC. Hence, the findings should be interpreted in light of this constraint.

Practical implications - Knowledge officers should integrate multiple HRD programs so that knowledge transfer is organically linked to knowledge creation by combining off-the-job training, OJT and kaizen (continuous improvement) programs.

Originality/value - This paper constitutes one of the earliest works that analyzes the effect of HRD programs on integrating knowledge transfer and knowledge creation.

Keywords Knowledge creation, Human resource development, Knowledge transfer

Paper type Case study 


\section{Introduction}

Knowledge plays a central role in knowledge-based economics and, more particularly, in the economics of innovation because it fuels productivity, growth and the survival of organizations (Guechtouli et al., 2012; Kane, 2010). The knowledge-based theory of organizations views them as social communities specializing in speedy and efficient knowledge creation and transfer (Kogut and Zander, 1996; Reagans and McEvily, 2003). Therefore, knowledge management is recognized as a key generator of an organization's competitive advantage (Argote and Ingram, 2000; Kumar and Ganesh, 2009)[1].

Although numerous studies have investigated the mechanisms of creation and transfer of knowledge in organizations, little research has examined how to integrate knowledge transfer and creation. As Kumar and Ganesh (2009) suggested, knowledge transfer enables the exploitation of existing knowledge, while knowledge creation is akin to exploration of new ideas and concepts by combining existing knowledge. Thus, it may be possible to achieve a balance between "exploitation and exploration" (Benner and Tushman, 2003; March, 1991) by linking knowledge transfer and knowledge creation.

In examining this theme, the present study focused on the role of human resource development (HRD) programs in promoting knowledge transfer and creation. Some empirical research has reported that human resource $(\mathrm{HR})$ practices promote knowledge transfer and individual learning by establishing interpersonal relationships and developing knowledge stocks (e.g. Kase et al., 2009; Yamao et al., 2009; Zhao and Anand, 2009). Yet, few studies have examined how HRD programs facilitate knowledge transfer and creation in organizations.

The aim of this study was to explore a way to integrate knowledge transfer and creation through HRD programs, using a case study of the Toyota Technical Development Corporation (TTDC). Specifically, the research focused on the process of knowledge transfer from proficient engineers to less experienced engineers for subsequent knowledge creation.

The article is organized as follows. First, previous studies on knowledge, individual learning and expertise are briefly outlined. This is followed by an overview of intra-organizational knowledge transfer and creation. Next, a research question is proposed, based on the literature review. Then, the case of the TTDC is described. Finally, the case is discussed from theoretical and practical viewpoints.

\section{Theoretical background}

\subsection{Knowledge and expertise}


Knowledge creation cannot be viewed as separate from individual learning, because the absence of such a focus makes it difficult to inter-relate action and knowledge (Akbar, 2003; EasterbySmith et al., 2000). Organizations ultimately learn through their individual members (Kim, 1993). Consequently, the literature on the knowledge acquisition process at the individual level is reviewed in this section.

In cognitive psychology, knowledge is classified into declarative knowledge and procedural knowledge (Anderson, 1980). Declarative knowledge refers to knowledge about facts, while procedural knowledge is knowledge of a method or skill. This distinction originates in Ryle's (1949) classification of knowledge: knowing what and knowing how, although it is not easy to draw an exact line between the two types of knowledge (Smith, 1994). Declarative and procedural knowledge correspond to information and know-how, respectively - a distinction made in the "knowledge-based view of the firm" in which the firm is conceptualized as an institution for integrating knowledge (Grant, 1996; Kogut and Zander, 1996).

A person's knowledge or skill is thought to become more elaborate and effective with experience. That is, the more experience people have, the stronger the relationship becomes between their knowledge and performance. Anderson (1982, 1983) proposed three stages of knowledge acquisition:

1. the declarative stage;

2. knowledge compilation; and

3. the procedural stage.

This model proposes that knowledge is acquired as a set of facts at the verbal level (declarative stage) and that the knowledge is then converted into a procedural form with practice (knowledge compilation). Subsequently, there is fine tuning of the knowledge so that it can be applied more appropriately, and finally, there is a gradual process of acceleration (procedural stage).

Another classification is explicit knowledge and tacit knowledge. Explicit knowledge refers to knowledge that is transmittable in formal and systematic language, while tacit knowledge is hard to formalize and communicate because it is deeply rooted in action, commitment and involvement in a specific context (Nonaka, 1994; Polanyi, 1966). Experts use their abilities to acquire, store and utilize explicit and tacit knowledge of a specific domain (Sie and Yakhlef, 2009; Sternberg and Horvath, 1999). It can be said that most declarative knowledge is explicit, and some parts of procedural knowledge are tacit.

According to prior research on expertise, at least 10 years of active involvement in a specific field is necessary for an individual to reach an international level of achievement (Ericsson, 1996, 1999; Ericsson et al., 1993; Simon and Chase, 1973). This phenomenon is called "the 10-year rule of necessary preparation" (Ericsson, 1996). In domains such as chess, sports and music, the 
highest levels of observed public performance are only displayed after a minimum 10-year stage of intensive preparation.

It should be noted, however, that 10 years of experience does not guarantee expert performance. The amount and quality of "deliberate practice" is crucial for attaining a high level of performance (Ericsson, 1996, 1999; Ericsson and Lehmann, 1996). Deliberate practice refers to individualized training activities specially designed by a coach or teacher to improve specific aspects of an individual's performance through repetition and successive refinement (Ericsson and Lehmann, 1996). There are three features of deliberate practice:

1. well-defined tasks with an appropriate difficulty level for a particular individual;

2. informative feedback; and

3. opportunities for repetition and error correction (Ericsson, 1996).

Regarding the development process of the expert, Dreyfus and Dreyfus (1987) proposed a model consisting of five stages:

1. novice;

2. advanced beginner;

3. competent;

4. proficient; and

5. expert.

A novice would start from knowing nothing to being able to make a reasonable attempt at performing the skill, while an expert has a deep understanding of both situations and responses. Based on the 10-year rule and the 5-step model, it takes at least 10 years to go up the 5-step ladder from novice to expert in a specific domain. For ordinary people, it may take more than 10 years to become experts, and some people cannot reach that level.

\subsection{Knowledge transfer and creation}

New knowledge is created by individuals, but organizations play a critical role in articulating and amplifying that knowledge (Nonaka, 1994). Knowledge creation entities naturally shift from individual to inter-organization or social networks via group and organization systems and levels (Nonaka and Takeuchi, 1995; Wu et al., 2010). Individuals are presented with numerous opportunities to share their knowledge with other members of the organization (Reagans and McEvily, 2003). Extensive research suggests that an organization's ability to transfer knowledge effectively improves its range of activities, such as learning, competence and coordination 
(Ringberg and Reihlen, 2008). Knowledge transfer has been well-studied in an array of settings, including intra-organizational, inter-organizational and cross-border exchanges (Zhao and Anand, 2009). Among the three types of transfer, this study focuses on intra-organizational knowledge transfer, which is defined as the process through which one network member is affected by the experience of another in an organization (Argote and Ingram, 2000). Maurer et al. (2011) conceptualized knowledge transfer as the mobilization, assimilation and use of knowledge resources.

Although knowledge transfer among organizational units provides opportunities for mutual learning that stimulate the creation of new knowledge, knowledge is often "sticky" and "difficult to spread" (Szulanski, 1996; Tsai, 2001). With regard to the stickiness of knowledge, some researchers are opposed to the concept of "knowledge transfer". Critics state that best practices cannot simply be shared or transferred because knowing is inseparable from its constituting practice (Orlikowski, 2002). Cook and Brown (1999) argued that people generate knowledge through "knowing" or interacting with the world using others' knowledge as a tool. The interplay between knowledge and knowing through action is the source of obtaining new knowledge (King and Ranft, 2001).

Numerous empirical studies on intra-organizational knowledge transfer have confirmed that knowledge transfer across units is possible because managers are able to create a collaborative context through culture and organizational structure (Gooderham et al., 2011). Inkpen and Tsang (2005) suggest that knowledge transfer is facilitated by intensive social interactions by organizational actors. Similarly, Maurer et al. (2011) reported that the transfer of knowledge resources mediates between organization members' intraorganizational social capital, organizational performance outcomes of growth and innovation performance. Knowledge management literature suggests the need for a better understanding of the emerging community view of knowledge, where knowledge is embedded in human actions and interactions (Jakubik, 2011). Communities of practice are considered an adequate place for transferring knowledge from experts to less competent individuals (Guechtouli et al., 2012).

Knowledge transfer in organizations occurs through a variety of mechanisms, including personnel movement, training, communication, observation, replicating routines, patents, interactions with suppliers and customers and alliances (Argote et al., 2000). Kase et al. (2009) reported that (HR) practices contribute to establishing interpersonal relationships, which promote the transfer of knowledge internally. Yamao et al. (2009) also state that HR practices help develop knowledge stocks, which, in turn, facilitate knowledge transfer in multinational corporations. Specifically, Zhao and Anand (2009) found that collective teaching is effective in transferring both collective and individual knowledge. Following the research, this study examined the role of HRD programs in promoting knowledge transfer and creation.

The difference between knowledge transfer and knowledge creation should be noted here. McFadyen et al. (2009) argued that knowledge transfer involves the movement of facts, 
relationships and insights from one person or organization to another, while knowledge creation involves the generation of facts, relationships and insights that are new to the existing body of knowledge. Kumar and Ganesh (2009) also suggested that knowledge creation is akin to exploration, in which individuals and teams generate new ideas and concepts by combining existing knowledge; on the other hand, knowledge transfer enables the exploitation and application of existing knowledge. As existing knowledge influences the extent to which new knowledge is created (Smith et al., 2005), there are strong links between knowledge transfer, creation and innovation (Sankowska, 2013). Smith et al. (2005) defined an organization's knowledge creation capability as the extent to which employees have access to one another and other stakeholders, are capable of combining information and knowledge into new knowledge and perceive value from the exchange and combination process.

The factors that facilitate knowledge creation in organizations should be noted. Nonaka and

Takeuchi (1995) proposed five conditions for enabling organizational knowledge creation:

1. intention;

2. autonomy;

3. fluctuation and chaos;

4. redundancy; and

5. requisite variety.

Knowledge creation is driven by organizational intention, or an organization's aspirations and goals, and when organizational members are allowed to act autonomously. Fluctuation and creative chaos stimulate the interaction between the organization and the external environment. Sharing redundant information promotes the sharing of tacit knowledge, while organizational members can cope with many contingencies if they possess knowledge of the requisite variety. These five conditions may facilitate not only knowledge creation but also knowledge transfer within organizations.

Although various aspects of knowledge creation have been empirically studied in diverse contexts (Tsoukas, 2009), little research has been conducted to explore the linkage between knowledge transfer and knowledge creation. To balance exploitation and exploration in organizational learning (March, 1991), it is necessary for firms to understand how knowledge transfer is linked to knowledge creation.

\subsection{Research question}


Past research indicates the importance of fostering experts and transferring their knowledge to create knowledge to gain competitive advantage. Although numerous empirical studies have investigated the processes of transferring and creating knowledge, little research has examined how both processes should be integrated in organizations. The primary goal of this study was to investigate how knowledge is transferred from experts to less experienced employees, and how the transferred knowledge is used to create new knowledge, based on a case study of the TTDC. In particular, the present research focused on the role of HRD programs in facilitating knowledge transfer and creation. Thus, the following research question is proposed:

RQ. How do HRD programs promote the linkage between knowledge transfer and knowledge creation in engineering departments?

\section{Methodology}

\subsection{Research design}

This study adopted a single case study approach (Yin, 1994). A case study is a method by which the researcher explores a single entity or phenomenon bounded by time and activity and collects detailed information using a variety of data collection procedures over a sustained period of time (Cresswell, 1994). Yin (1994) argued that the single case is an appropriate design when the case represents:

1. a critical case tested from a well-formulated theory;

2. an extreme or unique case; or

3. a revelatory case.

Of these three rationales, the case of the TTDC can be regarded as a unique case because the firm is one of only a few organizations that have designed specific HRD programs for promoting knowledge transfer and creation.

\subsection{Data collection}

A series of semi-structured interviews was conducted with an executive officer, and a senior manager in charge of testing and material fields, at the TTDC. At the first interview, managers of the TTDC presented an overview of the HRD programs using internal documents. Then, the author asked questions about the details of the programs, as well as their effects on knowledge transfer and creation in the relevant fields. At the second and third interviews, the author asked questions about how the HRD programs have been developed and how engineers have reacted to the transformation. To collect data on managers' perceptions of the HRD programs, the author 
participated in a workshop where TTDC junior and middle managers of testing and material fields discussed their HRD programs. After the workshop, the author interviewed a vice president and an executive director of the TTDC on how they evaluated the HRD programs. In addition to interview data, internal documents of the TTDC were also used to analyze the case. The procedure for data collection described above is consistent with the triangulation of data sources and methods proposed by Yin (1994). All interviews were conducted in Japanese. The case was described by the author in Japanese, and the manuscript was checked by managers of TTDC. Then, the author translated the manuscript into English, which was checked and acknowledged by TTDC headquarters.

\section{The case of the TTDC}

\subsection{Company overview}

The TTDC is a subsidiary of the Toyota Motor Corporation. Its sales were 67.4 billion yen, and its number of employees came to 6,179 (as of April 1, 2014). The company was founded in 2006 by merging Toyota Techno Service, Toyota Max and Toyota Communication Systems. The TTDC provides vehicle design and development services to the Toyota Motor Corporation relating to engines, drivetrains, hybrid vehicles, fuel cells, electronics, chassis, vehicle bodies, testing, material engineering, computer-aided engineering, information technology (IT) systems, intellectual property design services, measurement and instrumentation control and facilities/equipment development and maintenance. Table I shows the organization of the TTDC. This paper focused on the fields of testing and material engineering, which have introduced a series of HRD systems.

The tasks of the testing field are to predict environmental performance (i.e. fuel consumption, aerodynamics, etc.), safety (i.e. strength reliability, collision safety, pedestrian protection, etc.) and comfort (i.e. silence, stability and controllability, air conditioning, universal design, etc.) using experimental and predictive techniques to incorporate them into product development plans and to develop and confirm vehicle performance of prototypes and mass produced cars.

In contrast, the material engineering field engages in developing, designing, testing, experimenting and analyzing materials for safe, eco-friendly and high quality vehicles. For example, the field is involved in developing various materials such as body materials, paint, clutch materials, hybrid vehicle batteries and motor materials. In the following sections, the HRD programs that were implemented in the testing and material engineering fields are described. 


\subsection{Rationale behind the introduction of programs}

The TTDC has introduced HRD programs for knowledge transfer and creation. The company has a vision of "becoming a group of top level engineers" and has invested in the training and development of its employees. In particular, the TTDC has regarded on-the-job training (OJT) as a key factor for HRD and has promoted learning together through face-to-face communication between superiors and subordinates. The company has developed the world's leading technology by providing training and development that match the needs of various technological fields.

Specifically, the testing and material fields in the TTDC have developed HRD programs for employees in their first three years, which are important for their future growth as engineers, and have provided proficient engineers with support systems for innovation. This study examined and describes the three programs that the testing and material fields have introduced since 2010:

1. technology and skills transfer programs;

2. on-site practical programs; and

3. technological creation programs.

There are several reasons why the testing and material fields introduced these HRD programs. First, as the speed of technological innovation in vehicles is increasing, developing methods using apprenticeships has limitations. More structured and organizational HRD systems are needed to learn state of the art technologies. Second, as many employees have experience working at other firms before entering the TTDC and have diverse backgrounds, managers need to share skills and visions for staff development. Third, some newly hired staff aspire to engage in advanced tasks and will leave the company if they are not given the opportunity. To reduce the turnover rate for younger employees, it is necessary to provide them with an environment in which they can work that matches their aspirations, by showing them clear career visions and explaining the value of the tasks they engage in. For these reasons, the testing and material fields started to introduce HRD programs for knowledge transfer and creation.

\subsection{HRD perspectives}

Figure 1 shows the HRD perspectives of the testing and material fields. The vertical axis refers to the level of capabilities, while the horizontal axis represents time. The goal of development in the first three years is to become a fellow in the workplace. It is natural for new hires who have just graduated from high school or university not to understand the technical terms used in the workplace. It takes three years for young employees to be able to communicate with their superiors and understand what they say. 
Table I Organization of the TTDC and subject of this paper

\begin{tabular}{|c|c|c|}
\hline Group & Field & Division \\
\hline \multirow[t]{2}{*}{ R\&D Group A1 } & Engine Development Field & $\begin{array}{l}\text { Engine System Development Div., Engine Design \& Engineering Div., } \\
\text { Engine Calibration \& Engineering Div. }\end{array}$ \\
\hline & $\begin{array}{l}\text { Drivetrain Engineering Field } \\
\text { HV and FC Development Field }\end{array}$ & $\begin{array}{l}\text { Drivetrain Engineering Div., Drivetrain System Development Div. } \\
\text { HV Development Div. 1, HV Development Div. 2, FC Development Div. }\end{array}$ \\
\hline \multirow[t]{2}{*}{ R\&D Group A2 } & Electronic Engineering Field & $\begin{array}{l}\text { Electronics Engineering Div. 1, Electronics Engineering Div. 2, } \\
\text { Semiconductor Engineering Div., Vehicle Electronics Engineering Div. 1, } \\
\text { Vehicle Electronics Engineering Div. 2, Vehicle Electronics Experiment Div. }\end{array}$ \\
\hline & $\begin{array}{l}\text { Electronic Control System } \\
\text { Engineering Field }\end{array}$ & $\begin{array}{l}\text { Electronics Control Platform Engineering Div., Electronics Control } \\
\text { Engineering Div. 1, Electronics Control Engineering Div. 2, Electronics } \\
\text { Control Engineering Div. 3, Electronics Control Engineering Div. } 4\end{array}$ \\
\hline \multirow[t]{4}{*}{ R\&D Group B } & $\begin{array}{l}\text { Body Engineering Field } \\
\text { Chassis Engineering Field }\end{array}$ & $\begin{array}{l}\text { Body Engineering Div. } 1 \text { Body Engineering Div. 2, Body Engineering Div. } 3 \\
\text { Chassis Engineering Div. }\end{array}$ \\
\hline & Testing Field & $\begin{array}{l}\text { Vehicle Performance Development Div. 1, Vehicle Performance Development } \\
\text { Div. 2, Vehicle Performance Development Div. 3, Vehicle Performance } \\
\text { Development Div. 4, Vehicle Performance Development Div. 5, Vehicle Skill } \\
\text { Training Div. }\end{array}$ \\
\hline & Material Engineering Field & Material Engineering Div. \\
\hline & CAE Field & $\begin{array}{l}\text { CAE Technology Div. 1, CAE Technology Div. 2, CAE Technology Div. 3, } \\
\text { CAE Technology Div. 4, CAE Technology Div. 5, CAE Technology Div. 6, } \\
\text { CAE Technology Div. } 7\end{array}$ \\
\hline \multirow[t]{2}{*}{ R\&D Group C } & $\begin{array}{l}\text { IT \& Development Assistance } \\
\text { Field }\end{array}$ & $\begin{array}{l}\text { Engineering Information Administration Div., Regulation \& Certification Div., } \\
\text { Information Technology Solution Div. 1, Information Technology Solution } \\
\text { Div. 2, Development Support Div., CAD Engineering Development Div. }\end{array}$ \\
\hline & $\begin{array}{l}\text { Intellectual Property Business } \\
\text { Field }\end{array}$ & $\begin{array}{l}\text { IP Business Management Div., IP Information Business Div., IP Global } \\
\text { Business Div. }\end{array}$ \\
\hline \multirow{4}{*}{$\begin{array}{l}\text { Measurement \& } \\
\text { Instrumentation } \\
\text { Business Group }\end{array}$} & Measurement \& & Measurement Control Business Div. 1, Measurement Control Business Div. \\
\hline & Instrumentation Control & 2, Measurement Control Business Div. 3, Measurement Control Business \\
\hline & Business Field & $\begin{array}{l}\text { Div. 4, Customer Business Div., Measurement \& Calibration Center Business } \\
\text { Div. }\end{array}$ \\
\hline & Facility Maintenance Field & $\begin{array}{l}\text { Measurement Facility Maintenance Div. 1, Measurement Facility } \\
\text { Maintenance Div. } 2\end{array}$ \\
\hline Administration & Company-Wide Management & Audit Dept., Corporate Planning Dept. \\
\hline Group & Administration Field & $\begin{array}{l}\text { Accounting Div., Procurement Div., General Administration Div., Human } \\
\text { Resources Div. }\end{array}$ \\
\hline
\end{tabular}

Note1: Based on homepage of theTTDC. Shaded fields are the subject of this paper

Note2: Research and Development (R\&D), Division (Div.), hybrid vehicle (HV), and fuel cell (FC).

However, employees in the fourth year cannot necessarily work independently in the workplace. Employees during their first three years usually work within a field, while employees in their fourth or fifth year need to understand the relationships with other fields and learn how to collaborate with people in other fields and propose ideas to them. It is necessary for them to propose hypotheses and to test them by themselves by the time they reach this point. It is only in their fifth year that they can work independently in the workplace. 
The developmental goal during the 6th to 10th years is to enhance optimization and efficiency on the job. Optimization means reasonably enhancing the quality and performance of functions, while efficiency refers to lean product and process development. In other words, engineers at this level can solve problems on the job using the plan-do-check-act (PDCA) process improvement cycle. Employees who enhance optimization and efficiency appropriately are considered fullfledged engineers.

Engineers during their 11th to 20th years aim to acquire the capability to identify issues and solve them effectively using the PDCA cycle. Engineers who have these capabilities are regarded as experts. "Optimization and efficiency" refers to solving problems that engineers face at work, while "innovation" means identifying new technological issues proactively and solving them in a creative way.

Engineers who reach expert level have to develop technology or take the initiative as managers. The developmental goals after the 20th year are to acquire management capabilities to identify future organizational and technological issues, and to plan and implement projects to solve them.

Figure $1 \mathrm{HRD}$ vision of testing and material engineering fields

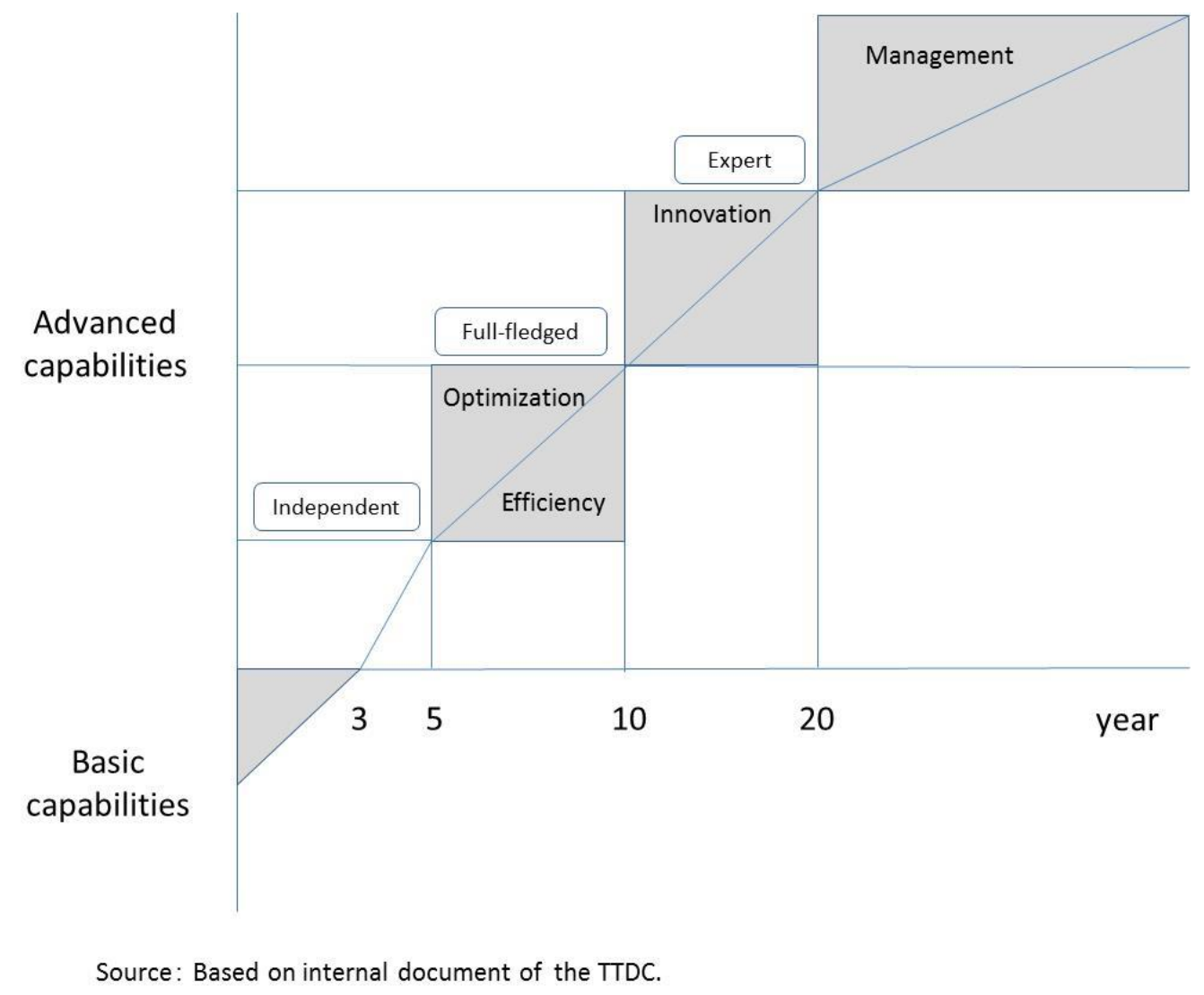




\subsection{Overview of HRD programs}

To realize the HRD policy, testing and material fields have introduced several training programs, shown in Figure 2. The purpose of the technological and skills transfer programs and the on-site practical programs was to develop the basic capabilities of employees with one-three years of experience through knowledge transfer from senior engineers, while technological creation programs have been introduced to enhance knowledge creation for optimization, efficiency and innovation in the TTDC. In addition, management enhancing programs aim at improving the understanding of management for managers or supervisors.

Figure 2 Overview of training programs in material engineering and testing fields

\begin{tabular}{|c|c|c|c|c|}
\hline \multicolumn{2}{|c|}{$\begin{array}{l}\text { Career stage } \\
\quad(\text { years })\end{array}$} & $\begin{array}{c}\text { Target of } \\
\text { Capabilities }\end{array}$ & Criteria & Types of training program \\
\hline \multicolumn{2}{|c|}{ More than 21} & $\begin{array}{c}\text { Sense of } \\
\text { management }\end{array}$ & $\begin{array}{l}\text { Being able to identify future organizational } \\
\text { and technological issues and to solve them } \\
\text { corporately }\end{array}$ & $\begin{array}{l}\text { Management enhancing } \\
\text { programs }\end{array}$ \\
\hline \multicolumn{2}{|c|}{$11-20$} & Innovation & $\begin{array}{l}\text { Being able to identify issues and to solve } \\
\text { them accordingly }\end{array}$ & \multirow{3}{*}{$\begin{array}{c}\text { Technological } \\
\text { creation programs }\end{array}$} \\
\hline & & $\begin{array}{l}\text { Optimization } \\
\text { \& Efficiency }\end{array}$ & Being able to solve problems on tasks & \\
\hline \multirow[b]{2}{*}{$1-5$} & $4-5$ & \multirow[b]{2}{*}{$\begin{array}{c}\text { Basic } \\
\text { capabilities }\end{array}$} & $\begin{array}{l}\text { Being able to propose hypotheses and to } \\
\text { test them }\end{array}$ & \\
\hline & $1-3$ & & $\begin{array}{l}\text { Understanding and mastering } \\
\text { engineering fundamentals and } \\
\text { principles }\end{array}$ & $\begin{array}{l}\text { On-site practical programs } \\
\text { Technology \& skills transfer } \\
\text { programs }\end{array}$ \\
\hline
\end{tabular}

Note: Figure based on internal document of TTDC; The shaded parts are subject of this paper. 
Figure 3 shows the relationships among the three programs. As explained above, technological and skills transfer programs, and on-site practical programs, are provided for employees with one-three years of experience. The former is for learning the fundamental and practical knowledge of engineering, the latter is for having experience of hypothesis-testing on site. As engineering knowledge is needed to propose hypotheses, both programs are closely related. The goal of these two programs was to develop basic engineering capabilities through knowledge transfer from senior engineers. The capabilities developed through the programs are utilized in programs for value-added technological creation. Although on-site practical programs are simulation-based, in which hypotheses are proposed that relate to well-identified phenomena already known to proficient engineers, technological creation programs aim at problem-solving or tackling issues in the workplace. That is, the technological and skills transfer programs and on-site practical programs are an investment in the employees, while the technological creation programs are for returns on the investment, for developing products. The three programs are described in the following sections.

Figure 3 Relationships among the three training programs
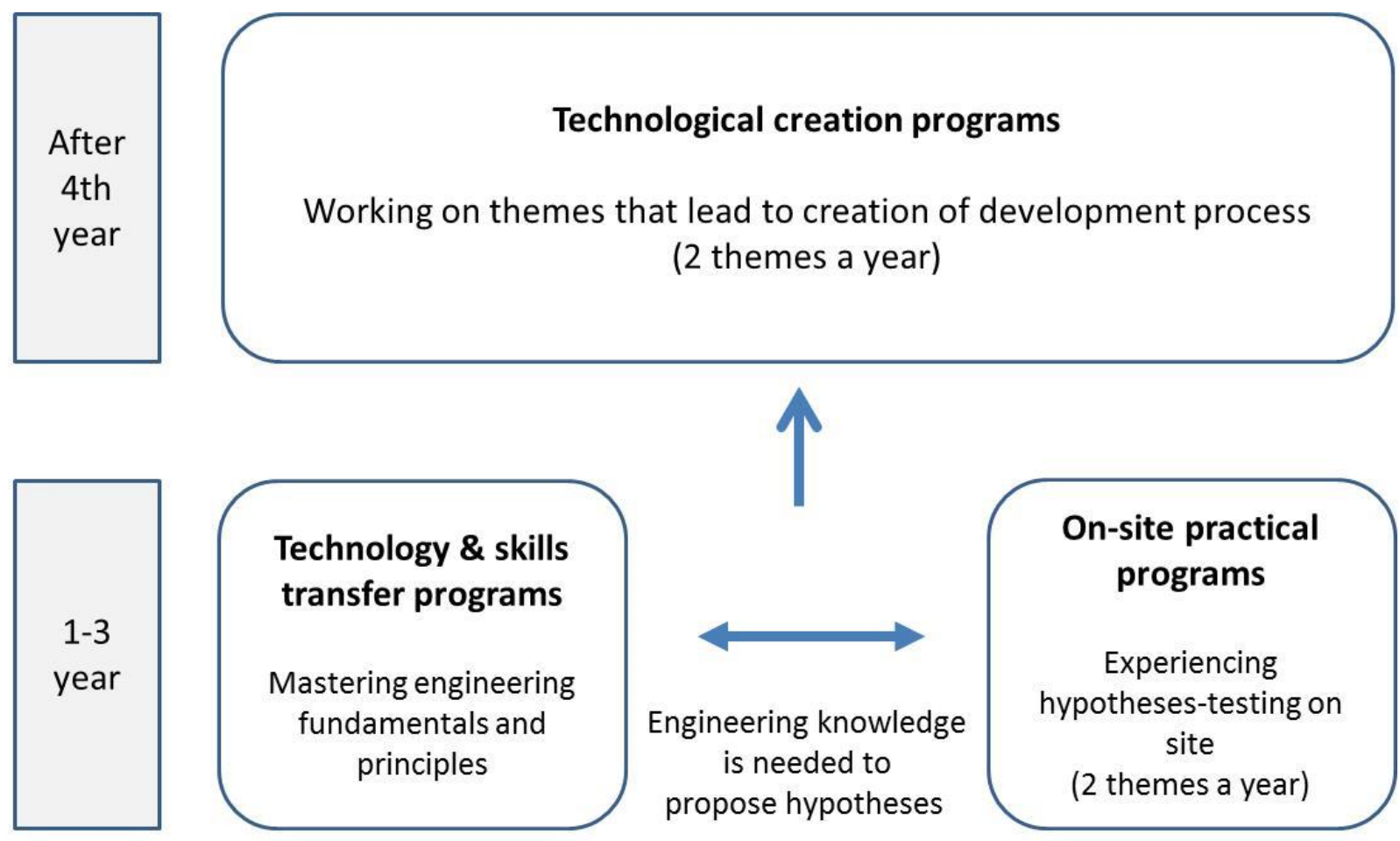

Source: Based on internal document of the TTDC. 


\subsection{Technology and skills transfer programs}

4.5.1 Background. In the technology and skills transfer programs, employees learn engineering fundamentals and principles, as well as practical knowledge in the workplace, because such knowledge is necessary to propose hypotheses. If you try to solve problems without appropriate hypotheses based on engineering knowledge, it does not contribute to technological development because you cannot logically explain the results. To develop technology, appropriate substantiation is always necessary.

As suggested earlier, many new hires would like to engage in advanced tasks, and some fail to continue if they are unable to do so. To prevent turnover like this, it is necessary to show younger employees images of potential career paths and to explain clearly what they should do at the present time.

The testing and material fields include more than 20 functions. Employees who enter the TTDC are in charge of a specific function until they reach an advanced level. Therefore, technology and skills transfer programs are implemented in each unit.

4.5.2 Contents. The testing and material fields launched their programs in 2010. As shown in Table II, there are three levels in the programs: basic (first year), applied (second year) and practical (third year). Employees learn the fundamental knowledge and principles of engineering in the basic program, the fundamental knowledge and principles of engineering related to automobiles in the applied program and imperative fundamental knowledge and principles for functional automobile development in the practical program. The testing and material fields consist of more than 20 functions, such as vibration, air conditioning, aerodynamics, fuel consumption and strength reliability, and the programs have been developed by engineers within each function.

Table II Technology and skills transfer programs

\begin{tabular}{lll}
\hline Level & Targets & Contents \\
\hline Practical & 3rd year employees (and applicants) & $\begin{array}{l}\text { Imperative fundamental knowledge and principles } \\
\text { for functional automobile development (Aiming at } \\
\text { improving capabilities for automobile production } \\
\text { development) }\end{array}$ \\
Application & 2nd year employees (and applicants) & $\begin{array}{l}\text { Imperative fundamental knowledge and principles } \\
\text { for individual function }\end{array}$ \\
Basic & 1st year employees (and applicants) & Fundamental knowledge and principles of engineering
\end{tabular}

Source: Based on internal document of TTDC 
For example, younger employees in the air conditioning function have classes on "temperature, amount of heat, heat conduction, and fluid measuring method" at the basic level; "control of vehicle's air conditioner, compressor, and basics of air-conditioning" at the applied level; and "past failure events, mechanisms of cool air leakage, and overview of HVs" at the practical level.

Specifically, a 1-hour class for one single theme is conducted once a week, which amounts to 48 lectures in total for a year. Within the class, a 20-minute lecture using an A3-sized summary is combined with a subsequent 40-minute discussion. That is, the class consists of a "transfer" session (20 minutes) and a "think" session (40 minutes). Participants reflect on their learning activities by writing what they feel and think on the "transfer program sheet" (an A4-sized paper format), and the management office collects them every three months to analyze the learning performance of the participants.

The program lecturers are engineers in their fourth or fifth year, but the lecture information and materials are checked by group leaders with more than 10 years of experience. The contents of the classes are revised every year, as lectures are conducted by different personnel.

4.5.3 Process. Many employees in the fields resisted participation in the programs when they started. There were complaints in the fields, such as "Why is this necessary?" "Previous methods worked well", "Just as I learned by myself, young employees should learn in the same way" and "We should not spoil young employees". The executive officer in charge of the fields involved explained its goals and vision to employees, and they reached the conclusion that "It's worth trying". Then, the programs formally started, as per the Executive Officer's decision.

As the CEO visited the classes and communicated with the participants at an early stage, the employees were motivated to participate in the programs. In the second year of the programs, senior engineers, who were instructors, had come to think, "We learned a lot by teaching", and then they spontaneously started to come up with other plans for developing engineers, such as "Let us design this program". Data from the "transfer program sheets", which are submitted every three months, show that participants' attitudes have become more proactive, as they have experienced the programs. Younger employees seem to be aware of personal growth through the programs in which practical knowledge is transferred from superiors in the workplace. As a result, the turnover rate of younger employees has decreased, as the programs were introduced.

\subsection{On-site practical programs}

4.6.1 Background. Engineers in the testing and material fields need to acquire the capability to propose hypotheses and test them, because they have the role of setting goals for product development and generating the plans to attain them. Hypothesis-testing capabilities constitute the foundation for solving problems and identifying issues on the job. It is believed that employees who learned well in graduate school already have the capabilities to some extent, 
while employees who graduated with bachelor's degrees, from technical colleges, technical schools and high schools tend to have developed comparatively fewer capabilities, due to limited research experience. To become engineers at the level of optimization, efficiency and innovation, it is necessary for them to acquire the basics of hypothesis-testing capabilities during their first three years in the workplace.

However, it is difficult to acquire such capabilities in a short time. Engineers should learn how to propose hypotheses even though their appropriateness may be in question in the early stages. By doing so, their capabilities improve with practice. At the level of "optimization and efficiency", engineers are required to solve problems with appropriate and rational hypotheses. At the level of "innovation", it has been proven that hypothesis-testing capabilities have become the key requirements for identifying new issues and generating innovation.

4.6.2 Contents. In the on-site practical programs, younger employees learn hypothesis-testing capabilities in the workplace, where experiments are conducted for product development under the supervision of advisers with four-five years of experience as engineers. Specifically, participants propose two hypotheses a year and test them in the programs. There are cases where hypotheses cannot be tested appropriately, yet participants are still able to realize the importance of hypothesis-testing through the experience, based on their fundamental and practical knowledge of engineering. In addition, they are able to improve their logical thinking and implementation skills by tackling the themes.

Table III is an overview of the programs. Theme 1 is conducted for three months from June to August after entering the firm. Participants propose a report on "hypotheses, tests, and analyses" using an A4 format and receive feedback on the report from advisers. Advisers choose themes in which the mechanisms of the phenomena have already been identified in the workplace, and hypotheses can be proposed based on the fundamentals and principles of engineering. Participants can use two hours a day for the programs, and they periodically have meetings as a cross-functional group with four-five members to report and discuss their progress with one another.

In the second and third years, participants deal with more complicated themes, as compared to the first year; however, the solutions can still be predicted, to some extent, in the workplace. The training period is increased to ten months, while the time for the activities is only an hour a week. The student engineers work as individuals or in a group within each function.

4.6.3 Process. When the programs commenced in 2011, newcomers were just placed in on-site experiment groups during their first year. The hypothesis-testing practices on-site have been introduced since 2012. In the testing field, there are two types of employees:

1. professionals who predict performance in designing products; and

2. specialists who conduct experiments on-site. 
Table III On-site practical programs

\begin{tabular}{lllll}
\hline Career stage & $\begin{array}{l}\text { Phases of } \\
\text { practice }\end{array}$ & Length of time & Sizes of unit & Contents \\
\hline $\begin{array}{l}\text { Third year } \\
\text { Second year }\end{array}$ & $\begin{array}{l}\text { Theme } 4 \\
\text { Theme } 3\end{array}$ & $\begin{array}{l}\text { An hour a } \\
\text { week per head }\end{array}$ & $\begin{array}{l}\text { Individual or } \\
\text { group within a } \\
\text { function }\end{array}$ & $\begin{array}{l}\text { Theme that solutions may be predictable to some } \\
\text { extent. (Theme 4 should be more complicated than } \\
\text { theme 3) }\end{array}$ \\
First year & Theme 2 & $\begin{array}{l}\text { Two hours a } \\
\text { day per head }\end{array}$ & $\begin{array}{l}4-5 \text { people } \\
\text { within cross- } \\
\text { functional group }\end{array}$ & $\begin{array}{l}\text { Theme that has already being clarified with } \\
\text { mechanisms of phenomena on-site. Theme that } \\
\text { hypotheses can be proposed based on principles. } \\
\text { (Theme 2 should be more complicated than theme 1) }\end{array}$ \\
\hline
\end{tabular}

Source: Based on internal document of TTDC

Hierarchal relationships between them are often observed but good product development is not possible without cooperation between them. Thus, the teams were designed intentionally with four-five members involving both professionals and specialists in on-site practical programs. The aim of the designing teams was to develop respectful relationships between their members and to prevent them from forming hierarchal relationships by combining professionals with specialists.

Employees showed resistance to the programs when they were introduced, but project pioneers started the programs by saying, "It is worth doing." The engineers who have been trained by onsite practical programs are now developing rapidly as engineers, compared with other employees.

\subsection{Technological creation programs}

4.7.1 Background. Although the goal of the technology and skills transfer programs and on-site practical programs was to develop the basic capabilities of less experienced engineers through knowledge transfer, technological creation programs aim at generating advanced technological knowledge that is directly linked to product development capabilities. The latter programs can be regarded as activities that utilize the capabilities developed in the former programs in product development.

Given that professionals had practiced quality control activities up to that point, the technological creation programs have become substitutes for those, while the programs were new to the specialists. The purpose of the programs was to develop engineers at the level of optimization, efficiency and innovation so that engineers can not only solve operational problems but can also identify future issues and tackle them accordingly (Figures 2 and 3). As shown in Table IV, goals are set for each career level to attain.

4.7.2 Contents. The aim of the programs was to facilitate the process of the engineers acquiring problem-solving capabilities using the PDCA cycle based on themes appropriate for the level of 
the employees. Individuals work alone to determine themes and tackle them, although participants exchange opinions and information for an hour a week in a cross-functional group with a maximum of six members. Managers attend the meetings as advisers and the team meets for a year. Discussion among members from different functions allows them to learn from one another. Approximately 700 non-managers take part in the programs.

Participants work on two themes that they select. Specifically, they tackle the first theme from April to July, submit a report on the results, based on the PDCA cycle, and receive feedback from August to September. Then, they tackle the second theme from mid-September, submit a report on the results in January and receive feedback in February.

4.7.3 Process. The output of the programs is not directly linked to performance appraisal because there is a risk that some members would exaggerate their performance in their report, and programs may not be effective if results are associated with personnel evaluation systems. Technological creation programs aim at effective systems to enhance a mentality of improvement and deal with developmental issues. However, the results of the programs have an indirect influence on the participants' personal evaluations through their task performance.

There is a limitation to the programs, which relates to how technological creation generated through the program is shared. Although testing and material fields share technologies within each function, using the company-wide technology exhibition that is held once a year, the fields are still searching for systems through which knowledge and technology can be shared on a daily basis.

Table IV Technological creation programs

\begin{tabular}{lll}
\hline Level & Subject & Goals \\
\hline Step 3 & Leader or senior leader & $\begin{array}{l}\text { Be able to identify issues and to solve them using PDCA cycle } \\
\text { based on fundamentals and principles of engineering with } \\
\text { original technology }\end{array}$ \\
Step 2 & Acting-leader & $\begin{array}{l}\text { Be able to solve operational problems using PDCA cycle based } \\
\text { on fundamentals and principles of engineering with original } \\
\text { technology } \\
\text { Be able to propose and test hypotheses on operational } \\
\text { problems, and analyze results based on fundamentals and } \\
\text { principles. }\end{array}$ \\
\hline Step 1 & Staff or advanced staff \\
\hline
\end{tabular}

Source: Based on internal document of TTDC 


\section{Findings}

The purpose of this study was to examine how HRD programs promote the integration of knowledge transfer and knowledge creation in engineering departments through the case of the testing and material engineering fields of the TTDC. These fields have introduced three HRD programs including "technology and skills transfer programs", "on-site practical programs" and "technological creation programs" for transferring and creating knowledge. Based on the fivestep model proposed by Dreyfus and Dreyfus (1987), the first two programs may help younger employees develop from "novice" to "competent" level, while the third program is for developing employees at the "proficient" or "expert" level. As shown in Table V, the case suggests that TTDC transfers explicit and tacit knowledge through off-the-job (technology and skills transfer programs) and OJT (on-site practical programs), and encourages engineers to use the transferred knowledge to create more advanced knowledge for vehicle development through kaizen (continuous improvement) programs (technological creation programs).

\section{Conclusions}

\subsection{Theoretical implications}

This study contributes to the existing research by clarifying the role of HRD programs in linking knowledge transfer to knowledge creation. The findings of this study extend previous research on knowledge management in four important ways. First, the testing and material fields of the TTDC transfer explicit knowledge (the fundamentals and principles of engineering) and tacit knowledge (hypothesis-testing capabilities), which are needed for creating advanced knowledge for vehicle development in the engineering departments. This corresponds to the view that existing knowledge influences the extent to which new knowledge is created (Smith et al., 2005), and that knowledge transfer, creation and innovation are inter-related (Sankowska, 2013). However, it is not enough just simply to link knowledge transfer to knowledge creation. This case study suggests that it is important to identify critical knowledge or capabilities that can be a basis for subsequent knowledge creation in designing HRD programs. In the testing and material fields of the TTDC, the critical capabilities are "the fundamentals and principles of engineering" and "hypothesis-testing capabilities", which are both necessary for generating innovation in vehicle production. As Nonaka and Takeuchi (1995) have suggested, new knowledge relating to vehicle production is created through interactions between explicit knowledge (fundamentals and principles of engineering) and tacit knowledge (hypothesis-testing capabilities), which are transferred through HRD programs.

Second, the TTDC promotes the transfer of explicit and tacit knowledge by combining off-thejob and OJT that is well-designed to promote "knowing" (Cook and Brown, 1999) and "deliberate practice" (Ericsson, 1996, 1999; Ericsson and Lehmann, 1996). Specifically, the 
fundamentals and principles of engineering, the explicit knowledge, are transferred through offthe-job training, where lecturers directly teach codified knowledge to less experienced employees through lectures and discussions. In contrast, the hypothesis-testing capabilities involve tacit knowledge and are transferred through OJT where younger employees learn by doing under the instruction of advisers. It can be said that the "technology and skills transfer programs" and the "on-site practical programs" complement one another to facilitate younger employees' "knowing" or interacting with the world using others' knowledge as a tool (Cook and Brown, 1999). That is, on-site practical programs may facilitate the process whereby less experienced employees acquire tacit knowledge of hypothesis-testing using explicit knowledge of engineering, which they learned in the technology and skills transfer programs. The two programs may promote the interplay between knowledge and knowing through action (King and Ranft, 2001). In addition, it should be noted that both programs are designed on the basis of three features of "deliberate practice":

1. well-defined tasks with an appropriate difficulty level for each career stage;

2. informative feedback from lecturers or advisers; and

3. opportunities for repetition and error correction in the workplace (Ericsson, 1996, 1999; Ericsson and Lehmann, 1996).

Third, HRD programs are implemented in communities of practice in testing and material fields. Specifically, technology and skills transfer programs are operated by engineers of each function, and on-site practical programs encourage participants to acquire hypothesis-testing capabilities by having them work in cross-functional teams under the instruction of advisers. Previous research found that intra-organizational social capital, based on communities of practice, facilitates knowledge transfer (Inkpen and Tsang, 2005; Maurer et al., 2011), because knowledge is embedded in human actions and interactions (Jakubik, 2011). The present research indicates that HRD programs become effective when they are developed and operated in communities of practice that are considered to constitute a place for transferring knowledge from experts to less competent individuals (Guechtouli et al., 2012).

Finally, HRD programs in TTDC involve three of the five enablers of knowledge creation proposed by Nonaka and Takeuchi (1995): intention, autonomy and redundancy. Engineers can understand "organizational intention" by the HRD perspectives that specify development goals according to career stage. On-site practical programs and technological creation programs allow engineers to act "autonomously". Then, technology and skills transfer programs and on-site practical programs help engineers acquire common knowledge and skills that promote informational "redundancy" among engineers. These three conditions embedded within HRD programs may enable members to create valuable knowledge in the organization. Using the case study of NUMMI, Magnier-Watanabe (2011) found that Toyota's production system and the alignment of kaizen were supported by organizational characteristics involving a higher degree 
of autonomy, self-discipline and openness. It is possible to conclude that knowledge creation, based on an autonomous and open work environment with a clear vision, may be features of knowledge management in Toyota groups.

Table V Characteristics of HRD programs

\begin{tabular}{llll}
\hline HRD programs & Type of programs & Purpose of programs & Type of knowledge \\
\hline $\begin{array}{l}\text { Technology and skills } \\
\text { transfer programs }\end{array}$ & Off-the-job training & Knowledge transfer & $\begin{array}{l}\text { Explicit knowledge } \\
\text { (fundamentals and principles } \\
\text { of engineering) }\end{array}$ \\
$\begin{array}{llll}\text { On-site practical } \\
\text { programs }\end{array}$ & On-the-job training & Knowledge transfer & $\begin{array}{l}\text { Tacit knowledge } \\
\text { (hypothesis-testing } \\
\text { capabilities) }\end{array}$ \\
$\begin{array}{l}\text { Technological creation } \\
\text { programs }\end{array}$ & $\begin{array}{l}\text { Kaizen (continuous } \\
\text { improvement) } \\
\text { programs }\end{array}$ & Knowledge creation & $\begin{array}{l}\text { Explicit \& tacit knowledge } \\
\text { (advanced knowledge for } \\
\text { vehicle development })\end{array}$ \\
\hline
\end{tabular}

\subsection{Practical implications}

The present research has managerial implications for knowledge transfer and creation. First, knowledge officers need to integrate multiple HRD programs so that knowledge transfer is organically linked to knowledge creation. In particular, it is important to identify the critical knowledge that forms the core competencies for a specific profession, and then to transfer that knowledge from the experts to the less experienced employees to create new knowledge using those competencies.

Second, knowledge officers should use OJT for transferring tacit knowledge and use off-the-job training for transferring explicit knowledge. The two types of training program need to be complementarily combined so that explicit knowledge transferred by off-the-job training is used as a tool to acquire tacit knowledge in OJT.

Third, HRD programs should be designed on the basis of the concept of "deliberate practice". As Ericsson (1996) suggested, programs have to include:

- well-defined tasks with an appropriate difficulty level for participants;

- informative feedback; and 
- opportunities for repetition and error correction.

Finally, HRD programs for knowledge transfer and creation need to be developed and operated in communities of practice in the organizations. Specifically, knowledge officers should motivate proficient employees to articulate their knowledge, transfer it within the workplace and create new knowledge based on the existing knowledge in a unit or department.

\subsection{Limitations and future research}

The limitations of this study should be acknowledged. First, the HRD programs described in this paper were introduced in only two departments of the TTDC. The characteristics of the departments may affect the content of the programs. Therefore, the findings should be interpreted in the light of this constraint.

Second, as the TTDC is expanding its HRD programs from the testing and material fields to other departments, it is necessary to follow up regarding the present situation relating to reform and to examine the transformation process.

Third, the HRD vision of testing and material engineering fields, shown in Figure 1, is based on an employee's tenure at the company. This reflects a traditional Japanese management style through which employees are hired and employed for the long term. Thus, it may be difficult for firms in other countries to apply this vision to their management systems.

Finally, this paper examined only one case study about the effect of HRD programs on knowledge transfer and creation. Thus, it is necessary for future research to investigate other cases and compare the results with those of the TTDC to gain insights into the relationship between HRD programs and knowledge management.

\section{Note}

1. The Toyota Technical Development Corporation will be amalgamated with the Toyota Motor Corporation in January 2016.

\section{References}

Akbar, H. (2003), "Knowledge levels and their transformation: towards the integration of knowledge creation and learning”, Journal of Management Studies, Vol. 40 No. 8, pp. 19972010 . 
Anderson, J.R. (1980), Cognitive Psychology and its Implications, Freeman, San Francisco, CA. Anderson, J.R. (1982), “Acquisition of cognitive skill”, Psychological Review, Vol. 89, pp. 369406.

Anderson, J.R. (1983), The Architecture of Cognition, Harvard University Press, Boston, MA.

Argote, L. and Ingram, P. (2000), "Knowledge transfer: a basis for competitive advantage in firms", Organizational Behavior and Human Decision Processes, Vol. 82 No. 1, pp. 150-169.

Argote, L., Ingram, P., Levine, J.M. and Moreland, R.L. (2000), "Introduction: knowledge transfer in organizations: learning from the experience of others", Organizational Behavior and Human Decision Processes, Vol. 82 No. 1, pp. 1-8.

Benner, M.J. and Tushman, M.L. (2003), "Exploitation, exploration, and process management: the productivity dilemma revisited", Academy of Management Review, Vol. 28 No. 2, pp. 238256.

Cook, S.D.N. and Brown, J.S. (1999), "Bridging epistemologies: the generative dance between organizational knowledge and organizational knowing”, Organization Science, Vol. 10 No. 4, pp. $381-400$.

Cresswell, J.W. (1994), Research Design: Qualitative and Quantitative Approaches, Sage Publications, Thousand Oaks, CA.

Dreyfus, H.L. and Dreyfus, S.E. (1987), Mind Over Machine: The Power of Human Intuition and Expertise in the Era of the Computer, Free Press, New York, NY.

Easterby-Smith, M., Crossan, M. and Nicolini, D. (2000), "Organizational learning: debates past, present and future”, Journal of Management Studies, Vol. 37 No. 6, pp. 783-796.

Ericsson, K.A. (1996), "The acquisition of expert performance: an introduction to some of the issues", in Ericsson, K.A. (Ed.), The Road to Excellence, Lawrence Erlbaum Associates, Mahwah, NJ.

Ericsson, K.A. (1999), "Creative expertise as superior reproducible performance: innovative and flexible aspects of expert performance", Psychological Inquiry, Vol. 10 No. 4, pp. 329-333.

Ericsson, K.A., Krampe, R.T. and Tesch-Romer, C. (1993), "The role of deliberate practice in the acquisition of expert performance”, Psychological Review, Vol. 100 No. 3, pp. 363-406.

Ericsson, K.A. and Lehmann, A.C. (1996), "Expert and exceptional performance: evidence of maximal adaptation to task constraints", Annual Review of Psychology, Vol. 47 No. 1, pp. 273305 . 
Gooderham, P., Minbaeva, D.B. and Pedersen, T. (2011), "Governance mechanisms for the promotion of social capital for knowledge transfer in multinational corporations", Journal of Management Studies, Vol. 48 No. 1, pp. 123-150.

Grant, R.M. (1996), "Toward a knowledge-based theory of the firm", Strategic Management Journal, Vol. 17 No. S2, pp. 109-122.

Guechtouli, W., Rouchier, J. and Orillard, M. (2012), "Structuring knowledge transfer from experts to newcomers", Journal of Knowledge Management, Vol. 17 No. 1, pp. 47-68.

Inkpen, A.C. and Tsang, E.W.K. (2005), "Social capital, networks, and knowledge transfer", Academy of Management Review, Vol. 30 No. 1, pp. 146-165.

Jakubik, M. (2011), "Becoming to know. Shifting the knowledge creation paradigm", Journal of Knowledge Management, Vol. 15 No. 3, pp. 374-402.

Kane, A.A. (2010), "Unlocking knowledge transfer potential: knowledge demonstrability and superordinate social identity", Organization Science, Vol. 21 No. 3, pp. 643-660.

Kase, R., Paauwe, J. and Zupan, A.N. (2009), "HR practices, interpersonal relations, and intrafirm knowledge transfer in knowledge-intensive firms: a social network perspective", Human Resource Management, Vol. 48 No. 4, pp. 615-639.

Kim, D.H. (1993), "Link between individual and organizational learning", Sloan Management Review, October, pp. 37-50.

King, A.W. and Ranft, A.L. (2001), "Capturing knowledge and knowing through improvisation: what managers can learn from the thoracic surgery board certification process", Journal of Management, Vol. 27 No. 3, pp. 255-277.

Kogut, B. and Zander, U. (1996), "What firms do? Coordination, identity, and learning", Organization Science, Vol. 7 No. 5, pp. 502-518.

Kolb, D.A. (1984), Experiential Learning: Experience as the Source of Learning and Development, Prentice-Hall, Upper Saddle, NJ.

Kumar, J.A. and Ganesh, L.S. (2009), "Research on knowledge transfer in organizations: a morphology", Journal of Knowledge Management, Vol. 13 No. 4, pp. 161-174.

Lave, J. and Wenger, E. (1991), Situated Learning: Legitimate Peripheral Participation, Cambridge University Press, Cambridge.

Lombardo, M.M. and Eichinger, R.W. (2010), The Career Architect: Development Planner, 5th ed., Lominger International, Minneapolis, MN. 
McFadyen, M.A., Semadeni, M. and Cannella, A.A. (2009), "Value of strong ties to disconnected others: examining knowledge creation in biomedicine", Organization Science, Vol. 20 No. 3, pp. 552-564.

Magnier-Watanabe, R. (2011), "Getting ready for kaizen: organizational and knowledge management enablers”, VINE, Vol. 41 No. 4, pp. 428-448.

March, J. (1991), "Exploration and exploitation in organizational learning", Organization Science, Vol. 2 No. 1, pp. 71-87.

Maurer, I., Bartsch, V. and Ebers, M. (2011), "The value of intra-organizational social capital: how it fosters knowledge transfer, innovation performance, and growth", Organization Studies, Vol. 32 No. 2, pp. 157-185.

Nonaka, I. (1994), "A dynamic theory of organizational knowledge creation", Organization Science, Vol. 5 No. 1, pp. 14-37.

Nonaka, I. and Takeuchi, H. (1995), The Knowledge-Creating Company: How Japanese Companies Create the Dynamics of Innovation, Oxford University Press, Oxford, NY.

Orlikowski, W.J. (2002), "Knowing in practice: enacting a collective capability in distributed organizing”, Organization Science, Vol. 13 No. 3, pp. 249-273.

Polanyi, M. (1966), The Tacit Dimension, Routledge \& Kegan Paul, London. Reagans, R. and McEvily, B. (2003), "Network structure and knowledge transfer: the effect of cohesion and range”, Administrative Science Quarterly, Vol. 48 No. 2, pp. 240-267.

Ringberg, T. and Reihlen, M. (2008), "Towards a socio-cognitive approach to knowledge transfer”, Journal of Management Studies, Vol. 45 No. 5, pp. 912-935.

Ryle, G. (1949), The Concept of Mind, Hutchinson, London.

Sankowska, A. (2013), "Relationships between organizational trust, knowledge transfer, knowledge creation, and firm's innovativeness", Learning Organization, Vol. 30 No. 1, pp. 85100 .

Sie, L. and Yakhlef, A. (2009), "Passion and expertise knowledge transfer", Journal of Knowledge Management, Vol. 13 No. 4, pp. 175-186.

Simon, H.A. and Chase, W.G. (1973), "Skill in chess”, American Scientist, Vol. 61, pp. 394-403.

Smith, E.R. (1994), "Procedural knowledge and processing strategies in social cognition", in Wyer, R.S. and Srull, T.K. (Eds), Handbook of Social Cognition, Vol. 1, Erlbaum, Hillsdale, NJ, pp. 99-151. 
Smith, K.G., Collins, C.J. and Clark, K.D. (2005), "Existing knowledge, knowledge creation capability, and the rate of new product introduction in high-technology firms", Academy of Management Journal, Vol. 48 No. 2, pp. 346-357.

Sternberg, R.J. and Horvath, J.A. (1999), Tacit Knowledge in Professional Practice: Researcher and Practitioner Perspectives, Lawrence Earlbaum Associates, Hillsdale, NJ.

Szulanski, G. (1996), "Exploring internal stickiness: impediments to the transfer of best practice within the firm", Strategic Management Journal, Vol. 17 No. 52, pp. 27-43.

Tsai, W. (2001), "Knowledge transfer in intraorganizational effects of network position and absorptive capacity on business unit innovation and performance", Academy of Management Journal, Vol. 44 No. 5, pp. 995-1004.

Tsoukas, H. (2009), "A dialogical approach to the creation of new knowledge in organizations", Organization Science, Vol. 20 No. 6, pp. 941-957.

Wu, Y., Senoo, D. and Magnier-Watanabe, R. (2010), "Diagnosis for organizational knowledge creation: an ontological shift SECI model", Journal of Knowledge Management, Vol. 14 No. 6, pp. 791-810.

Yamao, S., Cieri, H.D. and Hutchings, K. (2009), "Transferring subsidiary knowledge to global headquarters: subsidiary senior executives' perceptions of the role of HR configurations in the development of knowledge stocks", Human Resource Management, Vol. 48 No. 4, pp. 531-554.

Yin, R.K. (1994), Case Study Research: Design and Methods, 2nd ed., Sage, Thousand Oaks, CA.

Zhao, Z.J. and Anand, J. (2009), "A multilevel perspective on knowledge transfer: evidence from the Chinese automotive industry”, Strategic Management Journal, Vol. 30 No. 9, pp. 959-983.

\section{About the author}

Makoto Matsuo can be contacted at: mmatsuo@econ.hokudai.ac.jp 